\title{
Contestation In Development Communication Design of Religion: Efforts for Strengthening Religious Tolerance (Case Study at Yogyakarta Goverment)
}

\author{
Dr.Hasan Sazali,MA \\ Lecturer at Da'wah Faculty, State Islamic University (UINSU), Medan, Indonesia
}

\begin{abstract}
This study purposes to analyze the roles of Yogyakarta's government, along with the authorities in strengthening religious tolerance. It is analyzed through structural and cultural approaches. Structural approach is the bureaucrat approach of the various governmental institutions related to the religion development, especially in the aspect of religious tolerance. Also, the model of personal communication design development of religion offered in this study is expected to be a model in developing the communication system of religion. Moreover, the cultural approach is built on the basis of society by analyzing the optimization of the cultural value and local wisdom in the society, as well as seeing how much local wisdom and culture which exist in the society play a role in the process of strengthening religious tolerance. This study used qualitative approach with critical analysis. In addition, in order to complete the data comprehensively on some characteristics, quantification statistical perspective was conducted. The results showed that the government of Yogyakarta was relatively weak in strengthening religious tolerance, as well as the absence of communication design development of religion conducted by the government of Yogyakarta in strengthening religious tolerance in the government system. This role was taken over mostly by religious leaders who are members of the institution initiated by the community. However, it is institutionally supported by the government. Moreover, the initiatives of Yogyakarta's people are relatively strong in developing religious tolerance. The cultural value and local wisdom become the basis in strengthening are potential in the development process if the government is able to optimize the reinforcement base. On the contrary, the commercialization occurred to the cultural value and local wisdom in the system of people's lives in Yogyakarta.
\end{abstract}

Keywords: Religion Development Communication Design, Strengthening the Religious Tolerance

\section{INTRODUCTION}

Religions manifested in various embodiments, as seen in the systems of thought, also in the form of beliefs and norms. Religions also manifested in the form of worship system which appeared in their houses of worship and religious traditions. They were more visible in the form of association or religious institutions, such as the presence of religious groups and religious institutions as well as social and religious institutions. The authority of religious leadership was a factor that would determine the pattern of unity and religious tolerance. Along with the authority, religious leaders and their religious institutions solved issues which were not covered by the government.

According to Taher (1997: 5), "The roles of community leaders and religious leaders in the development including: translating the values, norms of religion in life, and the ideas of development into materials which could be understood by the public, giving opinions, suggestions and propriate criticism of the ideas and ways that were made to achieve successful development, also encouraging and guiding the society and religious communities to participate in developmental efforts. Furthermore, the form of communication strategy development undertaken by the government in improving inter-religious tolerance should also be able to perform a dialogical approach in order to implement the strategy of inter-religious dialogue from communities to optimize all the potentials of the community, thus they would be actively participated and involved in the process of development of religious tolerance..

The problem in this study was how did the government of Yogyakarta do the communication development design of religion in strengthening religious tolerance? It focused on these three issues:

1. How was the religious development communication design in strengthening religious tolerance performed by the regional head of Yogyakarta government?

2. How were the values of the locality adapted to support the strengthening of religious tolerance in building communication development design of religion conducted by the government of Yogyakarta?

Based on the research problem above, the aims of this study are:

1. Analyzing the policies of communication development design of religion in strengthening religious 
tolerance conducted by regional head of the government of Yogyakarta.

2. Analyzing the optimization of adaptation values of the locality in communication development

design of religion to strengthen religious tolerance by the government of Yogyakarta.

\section{METHOD OF RESEARCH}

The study was conducted by using a case study approach. The case study was a research strategy in which carefully investigating a program, event, activity, process, or group of individuals. The cases are limited by the time and activity, and researcher collected information using a variety of data collection procedures based on a predetermined time. Creswell (2010: 20) In general, the case studies was a strategy which was more suitable when the topic question of the study was how or why, when researchers had little chance to control events that would be investigated, and if the focus of the research was in the contemporary phenomenon in the context of real life. Yin (2015: 1)

This study is done to investigate cases in real life contexts and provided an explanation, meaning, and the expansion of research studied, with a holistic approach, especially on the roles of the administration in the government of Yogyakarta from the mayor, head of district (camat) to head of village (lurah), as well as governmental institutions which were involved in building communication design development of religion in order to strengthen religious tolerance.

In acquiring the findings of the analysis in this study, qualitative descriptive format in the form of case studies is carried out. The case study focuses on a particular unit of a variety of phenomena. Analysis of the data in this study carried out continuously since the beginning of the study until the end of the study. It was expected to generate findings and empirical explanation for the theory used complementary explanations. In the previous explanation described the steps taken in the process of data analysis in this study. First, found the theme of "tentative" topics from the conversation with the informant, by separating the information that had been obtained. Both key informants were not limited by a particular concept, but focused on the information needed in the study by considering the existing guidelines in details, because it would be less difficult in the process of coding data. Moreover, the quantification statistical perspective was performed to complete the data in order to more comprehensively on some characteristics.

\section{DISCUSSION}

Philosophical embodiment on the existence of Yogyakarta relied on Kraton Ngayogyakarta which specifically emitted the image of the city and built the image of Yogyakarta as the City of Culture, City of Heroism, City of Education and City of Tourism. Administratively, Yogyakarta consisted of 14 subdistricts and 45 villages. Regional Long Term

Development Plan 2005 - 2025, directed in bringing the people of Yogyakarta toward a life of a prosperous society, pious, dignity, characterized and meaningful. The vision of Yogyakarta in 2012 - 2016 is: "Yogyakarta as the Qualified Educational City, Characterized and Inclusive, Cultural tourism, and Central Services, with the Environmental and Economic Democracy". RKPD Yogyakarta (2013: 1). By the number of religions based on data from the Department of Population and Civil Registration, Yogyakarta residents was amounted to 413936 people which Islam as the majority. The number of Muslims in 2014 was 341548. As for the composition of the population of religion in Yogyakarta is in table 1:

Table. 1 The Composition of the Population of Religion in Yogyakarta

\begin{tabular}{|c|c|c|c|c|c|c|c|c|}
\hline \multirow[b]{2}{*}{ No } & \multirow[b]{2}{*}{ District } & \multicolumn{7}{|c|}{ Religion (People) } \\
\hline & & Islam & $\begin{array}{c}\text { Protest } \\
\text { ant }\end{array}$ & $\begin{array}{c}\text { Cathol } \\
\text { ic }\end{array}$ & $\begin{array}{c}\text { Hind } \\
\mathrm{u}\end{array}$ & $\begin{array}{c}\text { Budh } \\
\text { a }\end{array}$ & Konghucu & Native religious tradition \\
\hline 2 & Jetis & 20941 & 2718 & 4073 & 23 & 171 & 12 & 1 \\
\hline 3 & Gondokusuman & 32266 & 5499 & 4982 & 114 & 125 & 2 & 5 \\
\hline 4 & Danurejan & 17723 & 1380 & 2337 & 20 & 73 & 3 & 2 \\
\hline 6 & Ngampilan & 15998 & 1068 & 1645 & 41 & 89 & 0 & 0 \\
\hline 7 & Wirobrajan & 25503 & 1188 & 3970 & 37 & 62 & 1 & 0 \\
\hline 8 & Mantrijeron & 29709 & 1432 & 4363 & 34 & 79 & 0 & 2 \\
\hline 9 & Kraton & 19066 & 626 & 2786 & 22 & 1 & 0 & 1 \\
\hline 10 & Gondomanan & 11274 & 1763 & 2115 & 14 & 243 & 0 & 0 \\
\hline 14 & Kota Gede & 30753 & 907 & 1106 & 27 & 22 & 0 & 0 \\
\hline
\end{tabular}


Contestation In Development Communication Design Of Religion: Efforts For Strengthening Religious

\begin{tabular}{|lccccccc|}
\hline Jumlah & $\begin{array}{c}34154 \\
8\end{array}$ & 26995 & 43424 & 565 & 1362 & 26 & 16 \\
\hline
\end{tabular}

Source : Department of Population and Civil Registration in Yogyakarta (2014)

To achieve a harmonious religious life, one of the religious retreats made through places of worship. Yogyakarta owned places of worship as much as 1020. The number of houses of worship could be seen in table 2:

Table. 2

The number of houses of worship in Yogyakarta

\begin{tabular}{|c|c|cc|}
\hline No & House of worship & Total (Unit) & Presentage (\%) \\
\hline $\mathbf{1}$ & Mosque & 491 & $\mathbf{4 8 , 1 3}$ \\
\hline $\mathbf{2}$ & Catholic Church & 7 & $\mathbf{0 , 6 9}$ \\
\hline $\mathbf{3}$ & Protestant Church & 5 & $\mathbf{4 , 1 0}$ \\
\hline $\mathbf{4}$ & Buddhist Temple (Vihara) & 1 & $\mathbf{0 , 5 0}$ \\
\hline $\mathbf{5}$ & Hindu Temple (Pura) & 46 & $\mathbf{0 , 0 9}$ \\
\hline $\mathbf{6}$ & Musholla (Small Mosque) & 4 & $\mathbf{4 , 5 0}$ \\
\hline $\mathbf{7}$ & Chapel & 2 & $\mathbf{0 , 3 9}$ \\
\hline $\mathbf{8}$ & Pepanthan (?) & 1 & $\mathbf{0 , 1 9}$ \\
\hline $\mathbf{9}$ & Cetia (?) & 2 & $\mathbf{0 . 0 9}$ \\
\hline $\mathbf{1 0}$ & Chinese Temple & 1020 & $\mathbf{0 , 1 9}$ \\
\hline & Total & & $\mathbf{1 0 0}$ \\
\hline
\end{tabular}

Source: Ministry of Religious Affairs in Yogyakarta (2013)

By the total number of houses of worship in Yogyakarta, houses of worship was dominated by Muslims at $52.64 \%$, followed by the church at $4.70 \%$. , Yogyakarta residents who were Muslims amounted to $82.50 \%$ up until now, followed by Catholics at $10.49 \%$ and at $6,52 \%$ for Protestants. Yogyakarta Special Region through Law No. 13 of 2012 was agreed that the substance authority lied on five aspects, including the procedure for filling the position, position, duties, and responsibilities of Governor and Deputy Governor, Government Institutional of Yogyakarta, Culture, Defence and Spatial Planning. Regarding to historical factors, culture was one of the factors in building a particular privilege of Yogyakarta.

Communication design awakened when the interaction occurred. Interactions either individually or as a group at the level of social life was a foundation to the developmental process. The focus of research, started with the question, how to design communication that had been built by the Yogyakarta government with various institutions that was relevant to strengthening of religious tolerance; Ministry of Religious Affairs in Yogyakarta, FKUB Yogyakarta, religious counselors, and religious leaders. In a structural approach was to delegate tasks ranging from the mayor, camat, and lurah. The focus of this study was to analyze the strength of the communication design that had been done by the actors. In the approach to these actors, as agents of development we could not see them partially. Actors would comprehensively be analyzed both as individual, and as something that inherently in its individual. The development communication design of religion was a set of institutions associated with the development of religion, in government institutions, and institutions which formed the representation of the community in developing the strengthening of religious tolerance in Yogyakarta. Sazali (2016).

Communication religious developing in Yogyakarta did not work at all. Related to the Decree of the Minister of Religion and the Minister of Home Affairs Regulation No. 1 Year 1979 with Minister of Religious Affairs and the Minister of Home Affairs No. 9 of 2006, No. 8 Year 2006 on Guidelines for Implementation Task Regional Head / Deputy Head In maintaining the inter-religions harmony, Empowering Forum interreligions harmony, and Establishing the Houses of Worship. The city government did not understand the content of the regulations. One of them was how the roles existed in public system in the development of religion that was not optimized. It was because, their deprivation of systematically carried out by a group whom used religion as their legitimate power and justification.

Public policies were systemically related to communication design development of religion in the context of this study. The regulations made by the central government, when they came to the technical implementation issues to the level of city government, there were still some things not in line with the spirit of regional autonomy in involving communities in development. Furthermore, there were some problems technically related to the delivery of the message of regulation in communication design development of religion. The role of government was sublime, especially in the restrictions on the establishment of houses of worship that rose questions, especially when it was associated with the freedom of every citizen in the doing their religion, which 
the conditions in the realm of human rights that could not be eliminated non-derogable rights, as enshrined in Article 28 paragraph 1 of the Constitution of the Republic of Indonesia in 1945. The role of government at the level of the City government, in implementing the regulation, could lead to the spirit of the majority of the emphasis against minorities. Thus, the design was built from the previous system that had the same functions, with the government finally depolitization, in the name of maintaining the stability of society. Communication design development of religion involved in Yogyakarta was just a bit of community representatives who were involved continuously in the design process communication of religion, in presenting the strength values of religious tolerance in society. The community representative institutions did not get support from the government which institution only optimized existing social capital in a community environment. The optimized potential of the social capital that existed in society was represented by FPUB (Forum Brotherhood of the Faithful) continued to provide an understanding of "difference". The word 'difference' had strong meaning in society interaction. The government should force public institutions to optimize institutions which indirectly bridged the community and government. Yogyakarta government was required to strengthen the institutional structuring government agencies, involved in the development of religious tolerance. It started by strengthening strategic functions at FKUB level city government, by issuing regulations relating to PERDA. The institutional strengthening of this structure to the level of RT / RW, as well as cooperating with the media, both printed and electronic, as well as traditional local media in spreading messages of religious development in order to create public opinion in the harmony of religious tolerance.

For the next level, Yogyakarta government should think about how the concept of developing religion in the local context, to optimize the full potential of existing resources, in the beginning of understanding the shape of regulations relating to religious tolerance, how to socialize, as well as its implementation, which was connected to the Yogyakarta government services to the needs of Yogyakarta people in implementing their religious confidence. Building a communication synergy across sectors with the Ministry of Religious institutions of Yogyakarta had not been developed well, especially in the institutions of the Ministry of Religious Affairs, there was a functional position which always associated with religious communities, namely the extension of religion. During this extension the role of religion was less involved in the development of communication systems of religion.

In strengthening the development of communication systems of religion, which should be understood by the actors, that freedom of belief was the most fundamental rights in life, both on personal level and on collective level. The right to live freely in choosing faith, although was not experienced by everyone was essential for a life in dignity. Effendi (2013: 85). Regulations that were in the system of governance were tools to keep harmonious life in society, not as tools for the legitimacy of the ruling political opinion in the name of religion.

Figure. 1 Design and Strategic Process in Communication Development of Religion

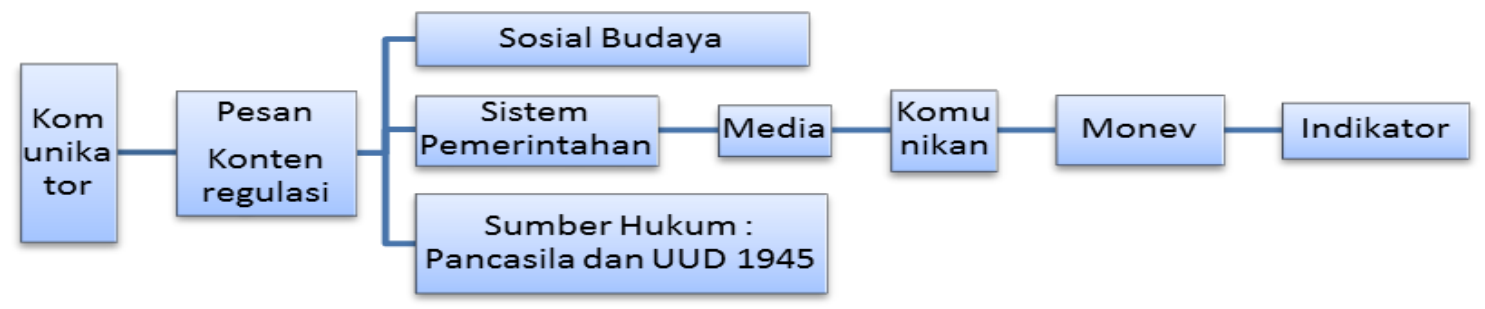

Source: Sazali (2016)

The government of Yogyakarta was part of governance in the province of Yogyakarta Special Region was also the center of the provincial capital. In preserving the values of the culture and local wisdom, the government of Yogyakarta, had PERDA that based on PERDA No.4 Yogyakarta Province in 2011, about the culture values in Yogyakarta. Dhewayani et al (2012: 148) stated the condition of the people of Yogyakarta and other parts of it were commonly heterogeneous. There were many races, colors, languages, religions, and ideologies either naturally or deliberately created to classify people on the basis of certain similarities. Human beings had a primordial element that referred to an individual's identity, included in this section was the primordial religion. The differences in religion or religious ideologies both cross and in-tra was a necessity for human life in symbols, and created symbols to exist in this life.

Cultural values and local wisdom became one strategic approach in strengthening religious tolerance both structurally and culturally that started from the community. Moreover, local wisdom and culture, at this point could no longer turn its existence in the system of civilization in other communities. Cultural values of Yogyakarta was Javanese culture that had spirit of actualization which was directed to all resources in an 
integrated (sawiji) in the determination and hard work which were dynamic (greget), accompanied by confidence in acting (sengguh), and would not retreat in any risk whatsoever (ora mingkuh) PERDA DIY N0.4. (2011: 3)

Diversity that was taught by a religion with a charity committed by its adherents was always performed in common practices. It was likely due to erroneous interpretations of the doctrine or because there were particular interests inside, as often happened in the social and political domains during this time. Whatever it was, this reality happened in the socio-religious life of our society. "Ambiguity of religion" had appeared among the ritual "slametan" Kholil A. (2008), which had been a tradition in Yogyakarta, especially by the Javanese. Slametan presented certain symbolism that required more detailed explanation to be understood correctly. "Sega golong", "manungsa" and "pecel pitik" for example, as symbolisms for nine holes in the body, "manunggaling kawula gusti" as a servant of God, and an effort to always get goodness. Slametan was ancestral traditions to accompany or mark changes in a person's life that meant "prayer" and expectations as religious expression to plead to be given "easy life" or kelempangan, blessing, good luck, good fortune that it all realized which could not be achieved without of interference by the God in it. In the context of the society in Yogyakarta, slametan had become a part of Javanese culture, with differences existing beliefs. This tradition had very strong values in society, as a media for uniting the people of Yogyakarta in the social system. Yogyakarta urban communities who underwent this ritual, proposed one common goal which was a harmony in social life.

Fundamentally, Yogyakarta had a big opportunity when compared to other regions, this was because the values of the culture and local wisdom already had legality strong enforcement of law specialty. Unfortunately, the government of Yogyakarta made their strong cultural values and local wisdom as a media commercialization in boosting the PAD (Regional Income) in the tourism sector, therefore, the values of local wisdom, the existing culture did not become world view largely people in Yogyakarta today. At this time, Yogyakarta required a system model associated with the communication of content regulation in religious tolerance. In this whole process of communication of the institutional actors whom involved should have the same portion in formulating standardization policies for the benefit of society. In this case, it would likely show a similar perception in addressing religious developments that occurred in society. There were some people who directly involved in the process of this communication system, including; City government agency representation with a variety of institutions involved in government unit (SKPD), among others: the Mayor and his subordinates were structurally, Kesbangpol. FKUB., Ministry of Religious Affairs in Yogyakarta, FPUB as the representation of religious figures as members of the organization, where they focused on strengthening religious tolerance existing in the community.

Based on the research that had been explained, there were several issues that could be discussed theoretically, that became a novelty in communication development theory especially that had been developed by Serveas. Religion development was one form of public service performed by the government. Furthermore, the communication development theory approach developed by Sarvaes whom analyzed the moral strength that had been built. The moral strength was the strength that came from normatively principles concerning human rights. Communication design development of religion, offered a new formulation associated with the development of communication systems and models of religion. System and religion development communication model were developed from models and communication systems that had been built by previous scientists. Systems and models of development communication religions offered more contextual, therefore it was possible to be developed with a variety of approaches, especially in regional autonomy.

\section{CONCLUSION}

Communication design development of religion in the religion tolerance sector had not become an important agenda in the development of Yogyakarta. It was a very poor response undertaken by the state institutions such as the Ministry of Religion Affairs and governmental institutions also the city government in establishing a communication design development of religion. Thus, by experiencing difficulties in monitoring and evaluating the broadcasting development of religious that led to the radicalism of religion in society. This condition was because of the low understanding of the content of Yogyakarta government regulations of religious tolerance. The next stage had hindered the communication process of the regulation both structurally and culturally.

\section{REFERENCES}

[1]. A.Kholil, 2008. Agama Dan Ritual Slametan (Deskripsi-Antropologis Keberagamaan Masyarakat Jawa) Jurnal Budaya Islam El-Harakah. Vol.10,N0.3, September-Desember 2008. hal. 187-202

[2]. Abdullah, I., 2002. Simbol Makna dan Pandangan Hidup Jawa. Analisis Gunungan Pada Upacara Grebeg. Balai Kajian Sejarah dan Nilai Tradisional. Yogyakarta

[3]. Abdullah, I., dkk, 2008. Agama dan Kearifan Lokal Dalam Tantangan Global. Pustaka Pelajar. Yogyakarta. 
[4]. Badan Pusat statistik Kota Yogyakarta, 2014. Kota Yogyakarta Dalam Angka 2014. Pemerinthahan kota Yogyakarta.

[5]. Creswell Jhon W, Research Design, Qualitative, Quantitaive, Mixe MethodsApproaches, edisi Terjemahan, Reseach Design, Pendekatan Kualitatif, Kuantitatif, dan Mixed, 2010, Cet.I, Pustaka Pelajar, Yogyakart

[6]. Dwiyanto, A, 2015. Manajemen Pelayanan Publik:Peduli, Inklusif, dan Kolaboratif. Edisi Kedua, Cet. IV. Gadjah Mada University Press. Yogyakarta

[7]. Effendi, D, 2013. Pluralisme dan Kebebasan Beragama. Cet.IV. Institut Dian Interfidei. Yogyakarta

[8]. Peraturan Bersama Menteri Agama dan Menteri Dalam Negeri No. 8 dan No. 9/2006, tentang "Pedoman Pelaksanaan Tugas Kepala Daerah/ Wakil Kepala Daerah dalam Pemeliharaan Kerukunan Umat Beragama, Pemberdayaan ForumKerukunan Umat Beragama, dan Pendirian Rumah Ibadah." 21 Maret 2006, http://hukum.unsrat.ac.id/men/menag_mendagri_2006.pdf (diakses 20 Juni 2014)

[9]. Peraturan Daerah Istimewa Yogyakarta N0 4 Tahun 2011

[10]. Peraturan Presiden (Perpres), 2010. Nomor 5 Tahun 2010 tentang Rencana Pembangunan Jangka Menengah Nasional (RPJMN) 2010-2014

[11]. Sazali,H., 2016, Penguatan Toleransi Agama dalam Komunikasi Pembangunan Agama, Studi Kasus Pemerintah Kota Bogor dan Yogyakarta. Disertasi. Program Studi Penyuluhan dan Komunikasi Pembangunan. Sekolah Pascasrajana Universitas Gadjah Mada. Yogyakarta

[12]. Servaes, J., Ed, 2007. Communication For Development And Social Change. Sage Publication India Pvt Ltd. India

[13]. Servaes, J., 1996. Human Rights, Partisipatory Communication and Cultural Freedom in Global Prespective. The Journal of International Communication, 5 (1 and 2) : pp 122-133 